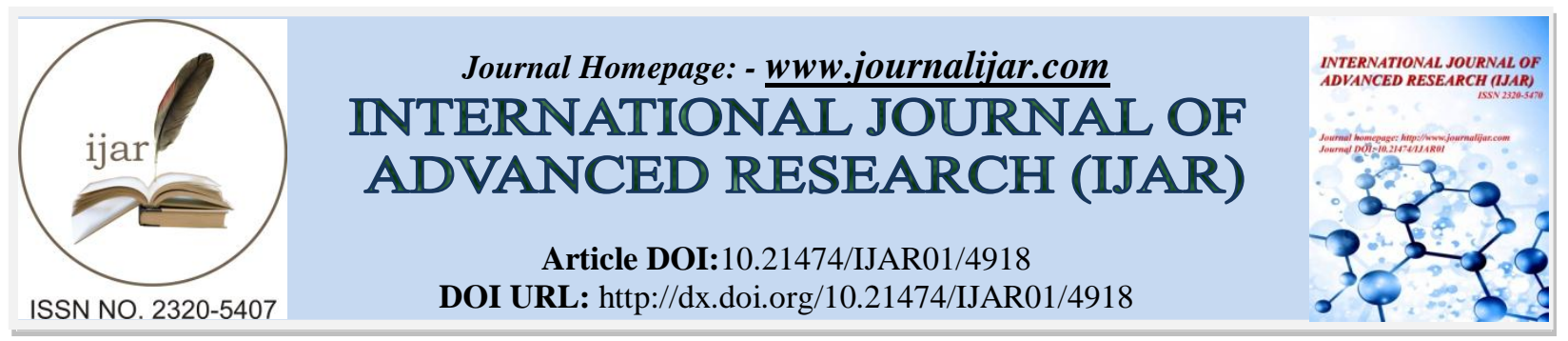

RESEARCH ARTICLE

\title{
ECONOMIC VALUE ADDED: A FINANCIAL TOOL FOR MEASURING CORPORATE PERFORMANCE WITH REFERENCE TO INDIAN AUTOMOBILE SECTOR.
}

\author{
Ganesh Prasad Panda ${ }^{1}$ and Santosh Kumar Panda ${ }^{2}$. \\ 1. Lecturer in Commerce, Sadhu Goureswar College, Kanikapada, Jajpur. Odisha, India. \\ 2. Lecturer in Costing, Government Engineering College, Keonjhar, Odisha.
}

\section{Manuscript Info}

.........................

Manuscript History

Received: 22 May 2017

Final Accepted: 24 June 2017

Published: July 2017

Key words:-

Economic Value Added, Market Value

Added, Corporate Performance

Measures, Shareholders Wealth

Creation, Value Based Management.

\section{Abstract}

It is universally accepted that the goal of financial management is to maximize the shareholder's value. In recent years, Economic Value Added (EVA) framework is gradually replacing the traditional measures of financial performance on account of its robustness and its immunity from creative accounting. Following this global trend, several companies in India are focusing on shareholders' value creation. The main objectives of this study were: to examine whether the sample companies has been able to generate value for its shareholders; to analyze the effectiveness of EVA over the conventional measures of corporate performance, and to indicate whether the significant differences exists between the values of EVA and other profitability measures of the sampled companies. Moreover, it also seeks to examine the value-creation strategies of selected Indian Automobile companies by analysing whether EVA better represents the market-value of companies in comparison to conventional performance measures. In this regards, EVA and the conventional measures of corporate performance are analysed. Moreover, various statistical tools like ANOVA, trend analysis and regression analysis are used for analysing the data.

Copy Right, IJAR, 2017,. All rights reserved.

\section{Introduction:-}

India is the fastest growing economy in the world. It has transferred the image of Asian economies and is playing a significant role in world affairs. The ever increasing gross domestic product (GDP) and strong economic policies have put India on a fast track development. India is transferring itself from an agrarian economy to an industrial economy. India has soon the growth rates that have made the world sit up and take notice (Dicken 2003). Economic Value Added (EVA) is the measure of company's true profitability and a strategy for creating and shareholders wealth. It is a vital measure of total productivity, which reflects all the dimensions by which the management can increase value. EVA is an estimate of true economic profit of the amount by which earning exceeds or fall short of required minimum rate of return, investors can get by investing in other securities of comparable risk. It is the net operating profit minus the appropriate charges for the opportunity cost of capital invested in a organization. The onset of globalization and liberalization of Indian economic has resulted shareholders value. In the present day required some managerial technique, which helps to measure organizational progress and achieve the organizational strategic goals.

Corresponding Author:-Ganesh Prasad panda. 


\section{Review of literature:-}

1. Stewart (1994) has expended that EVA is a powerful new management tool that has gained worldwide recognition as the standard tool of corporate performance. EVA presents an integrated framework of financial management and incentive compensation. The adoption of EVA system by more and more companies throughout the world clearly depicts that it provides an integrated decision-making framework, can reforms energies and redirect resources to create sustainable value for companies, customers, employees, shareholders and for managements.

2. Ochsner (1995) says companies that use shareholder value growth alone as a measurement for executive performance pay leave less-skilled management dependent on luck. Economic value added measures, with some modification and in varying forms, can serve as leading indicators of company performance. Thus, investors will use them to give managements a compass to steer by. A company that adopts economic value added (EVA) is likely to need a substantial education program for managers. It also may elect to state EVA in terms of operating profits and use of capital. This puts EVA in the role of a target-setting mechanism, which assures that EVA figures will be available to the board of directors and, if necessary, major shareholders for tracking and comparison purposes.

3. Grant (1996) found that the EVA concept may have everlastingly changed the way real profitability is measured. A survey was conducted that examines the empirical relations between EVA and corporate valuation. Results suggest that EVA significantly bangs the Market Value Added of a firm and that this wealth effect stems from the company's residual return on capital

4. Blair (1997) observed that the EVA has generated much interest in the business community. This financial tool advocates debt finance as evidenced by its basic formula, which uses the weighted cost as the cost of capital, thus becomes cheaper than equity, partly due to the tax deductible interest.

5. Burketteand Hedley (1997) explained that the EVA concept can be used to assess organizational performance known as economic profit; it can be applied for profit companies, public sector organizations and non-profit organizations. EVA is being used by these entities in a variety of ways, including as a management communication base, as a measure of corporate and divisional performance, to tighten management, shareholder interests and to emphasize the long-term benefits of industrial research and employee training.

6. Mayfield (1997) has sarcastically established that the shareholder value can be increased by investing in all those projects which give a positive NPV and by discounting al those products and projects whose return on capital is less than the cost of capital. The major task is to encourage the managers to create long-term value. The traditional accounting techniques are familiar with concept of residual value. When this concept is used in economic value measurement as a means of evaluating business performance it involves some important modification in traditional accounting concepts.

Objectives of the study:-

1. To make a conceptual study of EVA as a performance monitoring tool.

2. To examine the impact of financial performance indicators on EVA of sample companies.

3. To understand the different dimensions of EVA.

Research hypotheses:-

Hypothesis 1:-

H0 There is no significant impact of EPS on EVA.

H1 There is a significant impact of EPS on EVA.

\section{Hypothesis 2:-}

HO There is no significant impact of ROE on EVA.

H1 There is a significant impact of ROE on EVA.

\section{Hypothesis 3:-}

H0 There is no significant impact of ROCE on EVA.

H1 There is a significant impact of ROCE on EVA.

Hypothesis 4:-

HO There is no significant impact of ROA on EVA.

H1 There is a significant impact of ROA on EVA. 


\section{Research methodology:- Sources of the data:-}

The financial data and information for the study have been drawn from the secondary source. The prowess corporate databases developed by CMIE (center for monitoring Indian economy) and CLP (capital line plus) have been used as principal sources. Besides that is a lot of things have been borrowed from various Magazines \& journals. Many websites have also been referred for collecting much important information. Various articles and research papers form internet also have been used for gathering a lot of information to prepare this project report.

\section{Sampling design:-}

Ten companies of Indian automobile sectors listed and actively traded in BSE during the years 2004 to 2016 have taken. The names of those selected automobile companies are given below

Tvs motors atul auto scooters india

1. Magestic auto

2. Ashok leyland

3. Fords motors

4. Smlisuzu

5. Eicher motors

6. Marutisuzuki

7. Hindustan motors

Period of the study:-

The period for the study covered 9 years from 2004 to 2012 .and the essential data have been collected from 10 companies.

\section{Econometric modelling:-}

In order to understand the the impact of ROA, ROCE, ROE, EPS on Economic Value Added an empirical exercise is being carried out by taking panel data for automobile sector in India from the period 2004 to 2012 in a multiple linear regression framework. The Econometrics Model is written as follows:

$Y=\beta 0+\beta 1 \times 1+\beta 2 \times 2+\beta 3 \times 3+\beta 4 \times 4 \ldots \ldots \ldots+$ eit

$\mathbf{Y}=$ Dependent variable $=\mathrm{EVA}$

$\beta 0=$ Intercept term

$\beta 1=$ Co-efficient of EPS

$\beta 2=$ Co-efficient of ROE

$\beta 3=$ Co-efficient of ROCE

$\beta 4=$ Co-efficient of ROA

$\mathrm{x} 1, \mathrm{x} 2, \mathrm{x} 3, \mathrm{X} 4 \ldots \ldots . .=$ independent variables

$\mathrm{x} 1=\mathrm{EPS}$

$\mathrm{x} 2=\mathrm{ROE}[90]$

$\mathrm{x} 3=\mathrm{ROCE}$

$\mathrm{x} 4=\mathrm{ROA}$

$\boldsymbol{\varepsilon i t}=$ Residual term/ Error term

\section{Eva as a performance monitoring tool:-}

Economic value added is a financial performance measure which computes the true economic profits of a corporation. EVA is a measure that enables managers to see whether they are earning an adequate return on the capital employed in the business. EVA was in use long back to measure divisional performance. A paramount objective of management should be the creation of value for the firm. Thus, it is essential in strategic planning to manage the firm's resources with an objective of increasing the firm's market value.1 From an EVA perspective, the ultimate success of a firm is not measured only by its capacity to grow its sales, produce profits, or generate cash from its operations, but whether the firm's activities are creating value for its owners (Ehrbar 1998). According to economic theory, a firm is creating value if the net present value of all its investments is positive. 2 Quite simply, EVA is a measure that enables managers to see whether they are earning an appropriate return on the capital under their control. It is a measure of profit less the cost of capital employed and is the one measure that properly accounts for all the complex trade-offs, often between the income statement and balance sheet, in creating value (Pettit 2000). Formula:-EVA = NOPAT $-($ Invested Capital $\times$ WACC $)$ 


\section{Empirical analysis:-}

Descriptive Statistics:-

Descriptive analysis shows the mean, and standard deviation of the different variables of interest in this study. It also presents the minimum and maximum values of the variables which help in getting a picture about the maximum and minimum values a variable has achieved. Basically, the theory of EVA rests on two principal assertions: first, a company is not truly profitable unless it earns a return on invested capital that exceeds the opportunity cost of capital; and second, that wealth is created when a firm's managers make positive Net Present Value (NPV) investment decisions for the shareholders (Grant, 2003).Here EVA is taken as dependent variable and ROE, ROCE, EPS, ROA is taken as independent variable.

Table 1:-Descriptive Statistics.

\begin{tabular}{|c|c|c|c|c|c|}
\hline & EVA & EPS & ROE & ROCE & ROA \\
\hline Mean & 149.24 & 17.87186 & 14.27402 & 39.36123 & 1.56299 \\
\hline Median & 3.65 & 4.1 & 17.53 & 10.89 & 4.74 \\
\hline Standard Deviation & 432.81 & 67.05485 & 51.1334 & 292.4967 & 14.52782 \\
\hline Minimum & -277.51 & -63.47 & -158.01 & -438.23 & -66.59 \\
\hline Maximum & 2293.30 & 625.62 & 248.36 & 2614.625 & 49.52 \\
\hline
\end{tabular}

(Source: Excel output)

Correlation:-

Table 2:-Pearson Bivariate Correlation Coefficients.

\begin{tabular}{|c|c|c|c|c|c|}
\hline Variables & EVA & EPS & ROE & ROCE & ROA \\
\hline EVA & 1 & & & & \\
\hline EPS & 0.200584 & 1 & & & \\
\hline ROE & 0.035706 & 0.155387 & 1 & & \\
\hline ROCE & 0.14737 & 0.192941 & -0.17659 & 1 & 1 \\
\hline ROA & 0.342189 & 0.523728 & -0.0258 & 0.605852 & \\
\hline
\end{tabular}

(Source: Excel output)

\section{Regression analysis:-}

In order to understand the the impact of ROA, ROCE, ROE, EPS on Economic Value Added an empirical exercise is being carried out by taking panel data for automobile sector in India from the period 2004 to 2012 in a multiple linear regression framework. The Econometrics Model is written as follows:

$\mathrm{Y}=\beta_{0}+\beta_{1} \mathrm{x}_{1}+\beta_{2} \mathrm{x}_{2}+\beta_{3} \mathrm{x}_{3}+\beta_{4} \mathrm{x}_{4} \ldots \ldots \ldots+\varepsilon_{\mathrm{it}}$

$\mathbf{Y}=$ Dependent variable $=$ EVA

$\beta_{0}=$ Intercept term

$\beta 1=$ Co-efficient of EPS

$\beta 2=$ Co-efficient of ROE

$\beta 3=$ Co-efficient of ROCE

$\beta 4=$ Co-efficient of ROA

$\mathrm{x}_{1}, \mathrm{x}_{2}, \mathrm{x}_{3}, \mathrm{x}_{4} \ldots \ldots \ldots=$ independent variables

$\mathrm{x}_{1=}$ EPS

$\mathrm{x}_{2}=\mathrm{ROE}$

$\mathrm{x}_{3=} \mathrm{ROCE}$

$\mathrm{x}_{4=}=\mathrm{ROA}$

$\boldsymbol{\varepsilon}_{\mathrm{it}}=$ Residual term/ Error term

\section{Result:-}

\begin{tabular}{|l|l|l|l|l|}
\hline \multicolumn{2}{|l|}{ Summary output } & & & \\
\hline \multicolumn{2}{|l|}{ Regression Statistics } & & & \\
\hline Multiple R & 0.351722366 & & & \\
\hline R Square & 0.123708623 & & & \\
\hline AdjustedR & & & & \\
\hline Square & 0.085608998 & & & \\
\hline Standard Error & 413.8725521 & & & \\
\hline
\end{tabular}




\begin{tabular}{|l|r|r|r|r|}
\hline Observations & 97 & & \\
\hline & Coefficients & Standard Error & t Stat & P-value \\
\hline Intercept & 124.9069565 & 44.73677 & 2.792042 & 0.00637 \\
\hline EPS & 0.05110613 & 0.763013 & 0.066979 & 0.946743 \\
\hline ROE & 0.249079877 & 0.85591 & 0.291012 & 0.771697 \\
\hline ROCE & 0.483788047 & 0.715402 & -0.67625 & 0.500581 \\
\hline ROA & 11.63990407 & 4.282198 & 2.718208 & $0.007844^{*}$ \\
\hline
\end{tabular}

ANOVA:-

\begin{tabular}{|l|r|r|r|rc|}
\hline & & & & \multicolumn{2}{c|}{ Significance } \\
\hline & df & SS & MS & F \\
\hline Regression & & & & F \\
\hline Residual & 4 & 2224705 & 556176.4 & 3.246977 & 0.01539209 \\
\hline Total & 92 & 15758725 & 171290.5 & \\
\hline
\end{tabular}

EVA $=124.9+.051 * \mathrm{EPS}+.24 * \mathrm{ROE}+.48 * \mathrm{ROCE}+11.63 * \mathrm{ROA}$

$\mathbf{R}^{2}$ of0.123implies that the four independent variables are collectively able to explain $12 \%$ Variation in EVA.

F-statistic of 3.246and Sig. (F-Statistic) value of 0.015 shows that the model has statisticallysignificant explanatory power.

Intercept value of 124.906is the value of ratio of Total EVA of a company onan average evenwhen values of all independent variables are equal to 0 .

Hypothesis 1:-

Ho There is no significant impact of EPS on EVA.

H1 There is a significant impact of EPS on EVA.

Test of Hypothesis:-

EPS co-efficient of 0.05 implies that if the EPS of a company increases by 1unit then EVA of the company increases by 0.05 units and vice-versa. Further p-value $(0.946743)>.05$, so $\mathrm{H}_{0}$ is accepted, Hence EPS has no significant impact on EVA.

\section{Hypothesis 2:-}

HO There is no significant impact of ROE on EVA.

H1 There is a significant impact of ROE on EVA

\section{Test of Hypothesis:-}

ROE's coefficient ( $(3)$ of 0.249 implies that if ROE of a company increases by 1 unit then ratio of total debt to total assets of the company increases by 0.249 units and vice-versa. Further because p-value $0.77>.05$ so $\mathrm{H}_{0}$ is accepted and thus ROE has not statistically significant impact on the EVA.

\section{Hypothesis 3:-}

HO There is no significant impact of ROCE on EVA.

H1 There is a significant impact of ROCE on EVA.

Major findings:-

1. EPA has no significant impact on EVA.

2. ROE has not significantly affected the EVA of the company.

3. ROCE as a strategically insignificant impact on the EVA.

4. ROA has significant impact on $\mathrm{E}$.

\section{Conclusion:-}

EVA has been adopted by the advanced economies as financial performance measurement tool and corporate strategy which helped EVA to be identified as an important financial performance measurement tool over the conventional tools around the world. Though, there are mixed evidences on the superiority of EVA (Sharma \& 
Kumar, 2010), EVA has gained attention of corporate giants based on what EVA can be acclaimed to be the most recent and exciting innovation in company performance measures. There are very little evidences against the superiority of EVA over conventional financial performance measurement tools, which were defended in this paper. Though there are mixed evidences on EVA to be considered as the superior performance measure it has been claimed that the concept is the most useful measure of corporate performance (Chen \& Dodd, 1997). There is a scope for future research on EVA by taking the data of Malaysian public listed company for a particular time duration which will help to test the viability of the concept on the context of Malaysian business.

The reason that drives into working on this paper is due the state of knowledge in this area. It is aimed that it will give at least a basic idea of EVA and would be an opportunity to enhance knowledge and share with the audience and company management who are interested to make a move from the conventional financial performance measure to EVA.

\section{References:-}

1. Raiyani, J.R. and Joshi, N.K.(2011) EVVA based performance measurement: a case study o f SBI, HFDC Bank', Management Insight, Volume 7, Issue No. 1, June, pp. 31-43.

2. Damodaran(2002)_Corporate Finance: Theory and Practice', John Wiley and Sons, New Y ork, USA.

3. Sharma, A.K. and Kumar, S.(2010) Economic value added: literature review and relevant issues“, International Journal of Economics and Finance, Volume 2, Issue No. 2, May, pp. 200-220.

4. Irala, L. R.(2007)_Corporate performance measures in India: an empirical analysis', SSRN working paper series WP2007/01/A. Retrieved December. SSRN whtpp:??ssrn.com/abstract=964375.

5. Sivakumaran, D. and Sarvanakumar, M.(2011)_A recent analysis with respect to EVA and share price behavior of Indian Banks', European Journal of Economics, Finance and Administrative Sciences, Issue No. 42, pp. 112-120.

6. Young, D.S. and O‘Byrne, S.F.(2003)_EVA and value based management', Tata McGraw-Hill Publishing Company Ltd., New Delhi.

7. Vijaykumar, A.(2011) Economic value added and shareholders wealth creation: a factor a nalytic approach', Research Journal of Accounting and Finance, Volume 2, Issue No. 12, pp. 22-37.

8. Chattopadhaya, A. and Rakshit, D.(2010)_Measures of shareholders' value creation: an ass essment", Vidyasagar University Journal of Commerce, Volume 15, Issue 3, March, pp. 5-21.

9. Stewart, G.B.(1991) _The Quest for Value: A Guide for Senior Managers', First edition, H arper Business, NY.

10. Kumar, S. and Sharma, A.K.(2011)_Association of EVA and accounting earnings with ma rket value: evidence from India', Asia-Pacific Journal of Business Administration, Volume 3, Issue No. 2, pp.83-96.

11. Kaur, M., and Narang, S.(2009)_Insights on shareholder value addition from India's wealt h club: A study of selected companies', The IUP Journal of Accounting Research \& Audit Practices, Volume, 8, Issue No 3\&4, pp.20-51.

12. Stewart, G.B.(1994) EEVA: fact or fantasy ${ }^{6}$, Journal of Applied Corporate Finance, Volum e 16, Issue No. 2-3, pp. 91-99.

13. Weaver, S.C.(2001)_Measuring economic value added: a survey of the practices of EVA p roponents', Journal of Applied Finance, Volume 11, Issue No. 1, pp. 50-55.

14. Keys, D.E., Azamhuzjaev, M. and Mackey, J.(2001) Economic value added: a critical analysis‘, Journal of Corporate Accounting \& Finance, Volume 12, Issue No. 2, pp. 65-71.

15. Bhattacharya, A.K. and Phani, B.V.(2000)_Economic value added: in search of relevance‘ Decision, Vol. 27, No. 2, IIM Calcutta, pp. 25-54. 